\title{
Ethidium Bromide: Destruction and Decontamination of Solutions $\mathbf{s}^{1,2}$
}

\author{
GEORGE LUNN AND ERIC B. SANSONE \\ Environmental Control and Research Program, Program Resources, Inc., National Cancer Institute. \\ Frederick Cancer Research Facility, Frederick, Maryland 21701
}

Received November 11, 1986

\begin{abstract}
Ethidium bromide in water, TBE buffer, Mops buffer, and cesium chloride solution may be completely degraded by reaction with sodium nitrite and hypophosphorous acid. Only nonmutagenic reaction mixtures were produced. Destruction was $>99.8 \%$ in all cases; the limit of detection was $0.5 \mu \mathrm{g}$ ethidium bromide per milliliter of solution. Ethidium bromide also may be removed completely from the above solutions by using Amberlite XAD-16 resin. The limit of detection was $0.05 \mu \mathrm{g}$ ethidium bromide per milliliter of solution $(0.27 \mu \mathrm{g} / \mathrm{ml}$ when cesium chloride solution was used). 1987 Academic Press, inc.

KFY WORDS: ethidium bromide; disposal; recombinant technology; DNA; nucleic acid chemistry; fluorescence.
\end{abstract}

Ethidium bromide (EB), ${ }^{3}$ a powerful mutagen (1), is widely used in biomedical laboratories as an agent for visualizing nucleic acids. Highly visible fluorescent complexes are formed by intercalation. In spite of this wide use there are no validated methods of destruction. We report on our research into safe methods of disposing of this compound and decontaminating solutions by removal of EB. For the degradation studies we investigated a variety of methods including the use of potassium permanganate which is a general oxidative procedure for organic compounds, treatment with sodium hypochlorite, reduction with nickel-aluminum alloy in base (a technique previously used for de-

\footnotetext{
${ }^{1}$ The U.S. Government's right to retain a nonexclusive royalty-free license in and to the copyright covering this paper, for governmental purposes, is acknowledged.

${ }^{2}$ Research sponsored by the National Cancer Institute, DHHS, under contract NO1-CO-23910 with Program Resources, Inc. The contents of this publication do not necessarily reflect the views or policies of the DHHS, nor does mention of trade names, commercial products, or organizations imply endorsement by the U.S. Government.

${ }^{3}$ Abbreviation used: EB, ethidium bromide.
}

grading nitrosamines (2)) and deamination with hypophosphorous acid and sodium nitrite solution (a technique previously used for aromatic amines (3)). For the removal of EB from solution we investigated Mutasorb (cotton-bearing covalently bound trisulfocopper-phthalocyanine or "blue cotton") (4) and Amberlite XAD-16 resin (5) both of which have been reported to be capable of removing EB from solution. In the laboratory EB might be encountered in a variety of solvents so we investigated degradation and decontamination of EB dissolved in water, TBE buffer, Mops buffer, and cesium chloride solution. Reaction mixtures were assayed by fluorescence spectroscopy and checked for the absence of mutagenic activity.

\section{PROCEDURES}

Warning. Ethidium bromide is a potent mutagen. It is moderately toxic (6). It should only be handled with proper protective clothing in a functioning chemical fume hood. Hypophosphorous acid is corrosive and should be handled carefully. 
Materials. Cesium chloride, calf thymus DNA, Mops, and Tris were obtained from Sigma Chemical Co. (St. Louis, MO). Mutasorb was obtained from Pierce Chemical Co. (Rockford, IL). Ethidium bromide and all other reagents were obtained from Aldrich Chemical Co. (Milwaukee, WI). TBE buffer (pH 8.4) and Mops buffer (pH 5.3) were prepared as described by Maniatis et al. (7). The TBE buffer contained tris(hydroxymethyl)aminomethane $(0.089 \mathrm{M})$, boric acid $(0.089$ $M)$, and ethylenediaminetetraacetic acid $(0.002 \mathrm{M})$ and the Mops buffer contained 4morpholinepropanesulfonic acid $(0.04 \mathrm{M})$, sodium acetate $(12.5 \mathrm{mM})$, and ethylenediaminetetraacetic acid (1.25 mM). Ethidium bromide solutions in TBE buffer, Mops buffer, and water (ca. $0.5 \mathrm{mg} \mathrm{EB} / \mathrm{ml}$ ) and in cesium chloride solution $(1 \mathrm{~g} \mathrm{CsCl} / \mathrm{ml}$ ) (ca. $0.6 \mathrm{mg} \mathrm{EB} / \mathrm{ml}$ ) were prepared and these solutions were used in the degradation studies. Other solutions for use in the decontamination studies were prepared by diluting these solutions.

Fluorescence assay. A suitable chromatography system could not be devised but EB could be detected in solution by fluorescence spectrometry. EB fluoresces much more strongly in the presence of DNA (8) so a solution of DNA was added to the mixture to improve the limit of detection. For these determinations a TBE buffer was prepared as above and $0.1 \mathrm{M}$ sodium chloride was added. A DNA solution was also made up by dissolving about $20 \mu \mathrm{g} / \mathrm{ml}$ calf thymus DNA in the TBE/sodium chloride buffer. Then 100 $\mu l$ of the reaction mixture was mixed with $900 \mu \mathrm{l}$ buffer and $1.0 \mathrm{ml}$ DNA solution. After standing for at least $15 \mathrm{~min}$ fluorescence was determined (excitation $540 \mathrm{~nm}$, emission $590 \mathrm{~nm}$ ) using an Aminco-Bowman spectrophotofluorometer. The limit of detection was about $0.5 \mu \mathrm{g} / \mathrm{ml}$. When the amount of EB in buffer solution or water was to be determined (i.e., after the decontamination experiments) it was not necessary to add extra buffer and so $1 \mathrm{ml}$ of the solution to be de- termined was mixed with $1 \mathrm{ml}$ of the DNA solution and the fluorescence was determined as described above. In this case the limit of detection was $0.05 \mu \mathrm{g} / \mathrm{ml}$ except when the EB was dissolved in cesium chloride solution $(1 \mathrm{~g} / \mathrm{ml})$ which appeared to quench the fluorescence to some extent. In this case the limit of detection was approximately $0.27 \mu \mathrm{g} / \mathrm{ml}$. The limits of detection are lower in the decontamination experiments because the sample is not diluted with extra buffer. As a rough check these solutions can be checked for fluorescence by using a long wave uv lamp.

Mutagenicity assay. Although the foregoing procedure indicated the presence or absence of EB it gave no information as to the nature of the products. It could be that the EB was indeed degraded but it may have been converted to some other hazardous compound. Accordingly, we tested the final, neutralized, reaction mixtures using the plate incorporation technique of the Salmonella/ mammalian microsome mutagenicity assay essentially as recommended by Ames et al. (9) with the modifications of Andrews et al. (10). Tester strains TA98, TA100, TA1530, TA1535, and TA1538 were used and $100 \mu l$ of the reaction mixture was added to each plate. Liver homogenates (S9) were prepared from male Sprague-Dawley rats stimulated with Aroclor 1254. The protein concentration was $3 \mathrm{mg}$ per plate. The number of revertants over the background considered significant was established as twice the value of the cells alone. Ethidium bromide itself was mutagenic only to TA98 and TA1538 with activation but the other strains were included in an attempt to detect other mutagenic species which might be produced by the destruction processes.

Degradation methods. Each solution was degraded by each of the following methods.

A. About $0.13 \mathrm{~g}$ potassium permanganate was added per $3 \mathrm{ml}$ of EB solution. After stirring for $20 \mathrm{~h}$ the mixture was decolorized 
with sodium ascorbate and neutralized with acetic acid.

B. About $0.5 \mathrm{~g}$ potassium permanganate was added to $3 \mathrm{ml}$ of EB solution plus $6 \mathrm{ml}$ of water. Thus the ratio of oxidant to EB was increased. After stirring for $20 \mathrm{~h}$ the mixture was decolorized with sodium ascorbate and neutralized with acetic acid.

C. To $3 \mathrm{ml}$ of EB solution $3 \mathrm{ml}$ sulfuric acid $(6 \mathrm{M})$ was added followed by $0.25 \mathrm{~g}$ potassium permanganate. After stirring for $20 \mathrm{~h}$ the mixture was decolorized with sodium ascorbate and neutralized with solid sodium bicarbonate.

D. To $3 \mathrm{ml}$ of EB solution $6 \mathrm{ml}$ of sulfuric acid $(5 \mathrm{M})$ was added followed by $0.5 \mathrm{~g}$ potassium permanganate. Thus the ratio of oxidant to EB was increased. After stirring for $20 \mathrm{~h}$ the mixture was decolorized with sodium ascorbate and neutralized with solid sodium bicarbonate.

E. Three milliliters of commercial sodium hypochlorite solution $(\sim 5 \%)$ was added to 3 $\mathrm{ml}$ EB solution. After $20 \mathrm{~h}$ sodium ascorbate was added to remove the oxidizing power of the hypochlorite and the mixture was neutralized with acetic acid.

F. Six milliliters of commercial sodium hypochlorite ( $\sim 5 \%)$ was added to $3 \mathrm{ml}$ of EB solution. After $20 \mathrm{~h}$ sodium ascorbate was added and the mixture was neutralized with acetic acid.

G. Three milliliters of EB solution was basified with $3 \mathrm{ml}$ of potassium hydroxide solution $(2 \mathrm{M})$ and $0.3 \mathrm{~g}$ nickel-aluminum alloy was added. After $20 \mathrm{~h}$ the mixture was centrifuged and neutralized with acetic acid.

H. To each $3 \mathrm{ml}$ of solution $600 \mu \mathrm{l}$ of hypophosphorous acid (5\%) and $360 \mu$ l sodium nitrite solution $(0.5 \mathrm{M})$ were added. After 20 $\mathrm{h}$ the mixture was neutralized with solid sodium bicarbonate.

Decontamination methods. Solutions of EB $(40 \mu \mathrm{g} / \mathrm{ml})$ in water, cesium chloride solution, TBE buffer, and Mops buffer were stirred with Amberlite XAD-16 $(7 \mathrm{mg} / \mathrm{ml})$ for $20 \mathrm{~h}$ then the resin was removed by filtration and the solution was analyzed for the presence of EB. Solutions of EB $(4 \mu \mathrm{g} / \mathrm{ml})$ in the above-mentioned solvents were also stirred with Mutasorb $(5 \mathrm{mg} / \mathrm{ml})$ for $20 \mathrm{~h}$ then they were filtered and analyzed for the presence of EB. Solutions containing higher concentrations of EB $(100 \mu \mathrm{g} / \mathrm{ml})$ in the above solvents were also decontaminated by using larger amounts of Amberlite XAD-16 $(29 \mathrm{mg} / \mathrm{ml})$. Finally, a very concentrated solution of EB in cesium chloride solution (532 $\mu \mathrm{g} / \mathrm{ml})$ was decontaminated using Amberlite XAD-16 $(100 \mathrm{mg} / \mathrm{ml})$.

\section{RESULTS AND DISCUSSION}

The reaction mixtures from each method were tested for mutagenicity. Each method except for Method H (hypophosphorous acid and sodium nitrite) gave mutagenic reaction mixtures. Methods E and F (sodium hypochlorite) gave particularly mutagenic reaction mixtures. Sodium hypochlorite has been used for treating ethidium bromide solutions but, based on these results, we could not recommend the practice. Method $G$ (which we have successfully used in the past for degrading $N$-nitroso compounds (2)) also gave mutagenic reaction mixtures. Methods A-D gave mutagenic reaction mixtures although they were generally only marginally mutagenic. Blanks for Methods A-D (from which the ethidium bromide was omitted) were also sometimes mutagenic suggesting that the problem might be caused by the presence of manganese species or high salt concentrations rather than ethidium bromide or its degradation products. Increasing the relative amount of oxidant even further would significantly increase the volume of the reaction mixture and this did not seem practical.

The fluorescence assay was used to determine the residual amount of ethidium bromide with some of these Methods (Table 1). All the methods except Method $\mathrm{H}$ left some residue. This assay is not very specific (other 


\section{TABLE 1}

Destruction Procedures: AMOUNT OF ETHIDIUM BROMIDE REMAINING AFTER $20 \mathrm{~h}(\%)$

\begin{tabular}{ccccr}
\hline & \multicolumn{4}{c}{ Solvent $^{a}$} \\
\cline { 2 - 5 } Method & Mops & TBE & Water & CsCl \\
\hline A & 0.41 & 0.41 & 0.24 & 0.15 \\
C & $<0.2$ & $<0.2$ & 0.24 & $<0.19$ \\
E & $<0.2$ & 4.9 & $<0.2$ & $<0.19$ \\
G & $<0.2$ & 0.81 & $<0.2$ & $<0.19$ \\
H & $<0.13$ & $<0.13$ & $<0.13$ & $<0.11$ \\
\hline
\end{tabular}

${ }^{a}$ The initial concentration of EB was ca. $0.5 \mathrm{mg} / \mathrm{ml}$ in TBE buffer, Mops buffer, and water and ca. $0.6 \mathrm{mg} / \mathrm{ml}$ in $\mathrm{CsCl}$ solution.

fluorescent species could interfere) but the absence of fluorescent activity does indicate the absence of EB. Spiking experiments indicated that EB would have been detected if it were present.

Method $\mathrm{H}$ clearly gave the best results. EB could not be detected by the fluorescence assay, the reaction mixtures were nonmutagenic and the reagents (sodium nitrite and a dilute solution of hypophosphorous acid) are inexpensive and relatively nontoxic. Thus the method meets the key criteria of an ideal destruction procedure. The method is based on a deamination procedure previously published (3). It seems likely that it removes the amino groups from the EB and it may cleave the $\mathrm{N}$-containing ring. The only problem observed was that failure to add enough hypophosphorous acid to reduce the $\mathrm{pH}$ suffciently ( $\mathrm{pH}<3$, approximately) caused the reaction to fail.

The method should be periodically validated to ensure complete destruction. After the hypophosphorous acid has been added, the solution should be checked to ensure that it is strongly acid, and when the procedure is complete the solution should be checked for lack of fluorescence and, preferably, lack of mutagenic activity. Although we have tested this procedure only for EB dissolved in the solvents listed above, we see no reason why it should not work for EB in other buffers providing that sufficient hypophosphorous acid is added. Validation is, of course, essential. Addition of sodium nitrite to an acidic solution of an amine (either EB or a degradation product) might conceivably give rise to the formation of $N$-nitroso compounds, many of which are carcinogenic. However, model studies with dimethylamine showed no tendency to produce $N$-nitrosodimethylamine $(<0.07 \%)$. These reaction mixtures were also nonmutagenic.

An alternative approach to hazard control is the removal of EB from solution in some manner. Although the EB is not destroyed, the volume of hazardous material is greatly reduced, thus making disposal much easier. The decontaminated solution may be disposed of and the relatively small amount of adsorbent placed with the hazardous waste. We tested two reagents recommended for the adsorption of ethidium bromide: Mutasorb (blue cotton) and Amberlite XAD-16. Using the previously recommended (5) concentration of Amberlite XAD- $16(7 \mathrm{mg} / \mathrm{ml}$ of solution) we found that we could completely decontaminate solutions containing up to 40 $\mu \mathrm{g} \mathrm{EB} / \mathrm{ml}$ (Table 2). To decontaminate a somewhat more concentrated $(100 \mu \mathrm{g}$ EB/ml) solution which might be encountered in laboratory work it was necessary to raise the concentration of Amberlite XAD-16 to $29 \mathrm{mg} / \mathrm{ml}$. It was also found that, using the previously recommended (11) concentration of Mutasorb $(5 \mathrm{mg} / \mathrm{ml})$, solutions containing EB in concentrations up to 4 $\mu \mathrm{g} / \mathrm{ml}$ could be successfully decontaminated. Mutasorb could be used to decontaminate concentrated solutions of EB $(100 \mu \mathrm{g} / \mathrm{ml})$, but such large amounts were required that the liquid was completely soaked up in the cotton and it would be difficult to separate the two. The use of Mutasorb was not pursued further. Results with Amberlite or Mutasorb were found to be independent of the matrix containing the EB (i.e., water, TBE 
TABLE 2

Decontamination Procedures: Amount of Ethidium Bromide Remaining in SOlution AFTer 20 h (\%)

\begin{tabular}{lccc}
\hline Solvent & $\begin{array}{c}40 \mu \mathrm{g} \mathrm{EB} / \mathrm{ml} \text { treated } \\
\text { with 7 mg } \\
\text { Amberlite XAD-16/ml }\end{array}$ & $\begin{array}{c}100 \mu \mathrm{g} \mathrm{EB} / \mathrm{ml} \text { treated } \\
\text { with } 29 \mathrm{mg} \\
\text { Amberlite XAD-16/ml }\end{array}$ & $\begin{array}{c}4 \mu \mathrm{g} \mathrm{EB} / \mathrm{ml} \\
\text { treated with } \\
5 \text { mg Mutasorb/ml }\end{array}$ \\
\hline Mops & $<0.12$ & $<0.05$ & $<1.3$ \\
TBE & $<0.13$ & $<0.05$ & $<1.3$ \\
Water & $<0.12$ & $<0.05$ & $<1.2$ \\
CsCl & $<0.68$ & $<0.27$ & $<6.7$ \\
\hline
\end{tabular}

buffer, Mops buffer, or cesium chloride solution). The presence of cesium chloride increased the limit of detection, but did not appear to affect the decontamination efficiency. Of the two reagents we tested, Amberlite XAD-16 is clearly superior to Mutasorb. Apart from being much cheaper (about $\$ 0.07 / \mathrm{g}^{4}$ versus $\$ 12 / \mathrm{g}$ for Mutasorb), more EB is adsorbed per gram of adsorbent. Additionally, Mutasorb, which is a modified form of cotton, tends to absorb great quantities of water which increases handling problems. In contrast, the beads of Amberlite XAD-16 are easy to filter off.

\section{Recommended Procedures}

Destruction. To a solution of EB (ca. 0.5 $\mathrm{mg} / \mathrm{ml}$ ) in $100 \mathrm{ml}$ of water, TBE buffer, Mops buffer, or cesium chloride solution add $20 \mathrm{ml} 5 \%$ hypophosphorous acid solution and $12 \mathrm{ml} 0.5 \mathrm{M}$ sodium nitrite solution. Stir the mixture briefly and after $20 \mathrm{~h}$ neutralize it with sodium bicarbonate and discard.

N.B. The hypophosphorous acid solution is prepared by adding $10 \mathrm{ml}$ of the commercially available $50 \%$ solution to $90 \mathrm{ml}$ water and stirring briefly. It is probably advisable to prepare the hypophosphorous acid solution and the sodium nitrite solution (34.5 $\mathrm{g} /$ liter) fresh each day. If less concentrated

\footnotetext{
${ }^{4}$ Obtainable from Chemical Dynamics Corp., Hadley Rd., South Plainfield, New Jersey 07105.
}

solutions are to be decontaminated, it is probably a good idea to add the same volume of hypophosphorous acid and sodium nitrite solutions to ensure completeness of destruction. For more concentrated solutions these volumes should be increased pro rata. We have not investigated the destruction of EB at other concentrations or the treatment of EB in other buffers so modifications to this procedure must be validated by fluorescence spectroscopy and (if possible) mutagenesis testing.

Decontamination. To a solution of EB (ca. $100 \mu \mathrm{g} / \mathrm{ml}$ ) in $100 \mathrm{ml}$ of water, TBE buffer, Mops buffer, or cesium chloride solution add $2.9 \mathrm{~g}$ Amberlite XAD-16. After stirring for $20 \mathrm{~h}$, filter the mixture and place the beads with the hazardous waste. Discard the filtrate, which should appear clear. For lower concentrations of $\mathrm{EB}$ we recommend using the same quantity of Amberlite XAD-16 to ensure complete decontamination. For higher concentrations the amount of Amberlite XAD-16 should be increased pro rata. We have not exhaustively investigated the decontamination of highly concentrated solutions so this procedure must be validated by fluorescence spectroscopy.

\section{ACKNOWLEDGMENTS}

We thank Rohm and Haas for the generous gift of a sample of Amberlite XAD-16 and Dr. Alexandra Brown, National Institute of Diabetes and Digestive and 
Kidney Diseases, National Institutes of Health for advice and help with this project.

\section{REFERENCES}

1. MacGregor, J. T., and Johnson, I. J. (1977) Mutat. Res. 48, 103-108.

2. Lunn, G., Sansone, E. B., and Keefer, L. K. (1983) Carcinogenesis 4, 315-319.

3. Castegnaro, M., Barek, J., Dennis, J., Ellen, G., Klibanov, M., Lafontaine, M., Mitchum R., Van Roosmalen, P., Sansone, E. B., Sternson, L. A., and Vahl, M. (Eds.) (1985) Laboratory Decontamination and Destruction of Carcinogens in Laboratory Wastes: Some Aromatic Amines and 4-Nitrobiphenyl, World Health Organization, Geneva.

4. Hayatsu, H., Oka, T., Wakata, A., Ohara, Y.,
Hayatsu, T., Kobayashi, H., and Avimoto, S. (1983) Mutat. Res. 119, 233-238.

5. Joshua, H. (1986) BioTech. 4, 207-208.

6. Waring, M. (1975) in Antibiotics (Corcoran, J. W., and Hahn, F. E., Eds.), Vol. 3, pp. 141-165, Springer, New York.

7. Maniatis, T., Fritsch, E. F., and Sambrook, J. (1982) Molecular Cloning: A laboratory manual, Cold Spring Harbor Laboratory, Cold Spring Harbor, NY.

8. LePecq, J.-B., and Paoletti, C. (1967) J. Mol. Biol. 27, 87-106.

9. Ames, B. N., McCann, J., and Yamasaki, E. (1975) Mutat. Res. 31, 347-364.

10. Andrews, A. W., Thibault, L. H., and Lijinsky, W. (1978) Mutat. Res. 51, 311-318.

11. Pierce Chemical Co. (1985) Mutasorb, Pierce Chemical Co., Rockford, IL. 